\title{
Penguasaan Tanah Reklamasi tanpa Alas Hak atas Tanah: Studi Kasus di Desa Taddan, Kecamatan Camplong, Kabupaten
}

\section{Sampang}

\author{
Amri Ubaidillah \\ Brawijaya University, Indonesia \\ amriubaidillah181@gmail.com
}

\begin{abstract}
This study discuss legal issues concerning control of reclamation without possessing land rights as the result of the unregistered reclamation by communities in the Village of Tanddan, Sub-district Campling in the Sampang Regency. The aim of this study is to show legal implications and analyze effectivity of law enforcement on the accomplishment land control of reclamation without possession. By using empirical legal research with socio-juridical approach, the result of study shows that legal subject cannot control over and build houses over land of reclamation withou posession of land rights. In other words, houses built over land of reclamation without land rights can be evicted without any compensation. Therefore, such land of reclamation should be registered as the governmental land to the National Agrarian Board or Badan Pertanahan nasional (BPN) in the Sampang regency. It also affirms that there is a problem of effeciency of law enforcement on the accomplishment of land control of reclamation without any repressive and preventive measures.
\end{abstract}

KEYWORDS: Mastery, Land Reclamation, Without Rights.

\section{cc) (†) (9) Copyright $\odot 2018$ by Author(s)}

This work is licensed under a Creative Commons Attribution-ShareAlike 4.0 International License. All writings published in this journal are personal views of the authors and do not represent the views of this journal and the author's affiliated institutions.

\section{HOW TO CITE:}

Ubaidillah, Amri. "Penguasaan Tanah Reklamasi tanpa Alas Hak atas Tanah: Studi Kasus di Desa Taddan, Kecamatan Camplong, Kabupaten Sampang" (2018) 5:1 Lentera Hukum 159-170.

Submitted: January 31, 2018 Revised: February 02, 2018 Accepted: February 06, 2018 


\section{PENDAHULUAN}

Masyarakat dalam kehidupannya sangat bergantung pada tanah karena pentingnya peran tanah dalam kehidupan manusia. Pentingnya arti tanah bagi kehidupan manusia ialah karena dalam kehidupan manusia sama sekali tidak bisa dipisahkan dari tanah. Manusia hidup di atas tanah dan memperoleh bahan pangan dengan cara mendayagunakan tanah. ${ }^{1}$ Tidak dapat dipungkiri bahwa tanah merupakan salah satu aspek yang berperan dalam mewujudkan tujuan Negara Indonesia untuk kemakmuran rakyat sesuai dengan bunyi pasal 33 ayat (3) Undang-Undang Dasar 1945. Dengan tanah, penduduk diharapkan dapat mencapai penghidupan yang layak.

Seiring dengan berkembangnya waktu, kebutuhan akan tanah semakin besar. Hal tersebut diakibatkan oleh semakin padatnya penduduk di Indonesia, namun luas tanah tidak bertambah. Hal itulah yang membuat permasalahan tentang tanah semakin mengemuka. Dengan permasalah tersebut,dilakukan serangkaian h reklamasi guna menyiasati kekurangan lahan. Indonesia sebagai Negara Kepulauan, 79\% (7,1 juta km2) dari seluruh wilayah Indonesia termasuk Zona Ekonomi Eksklusif sebesar 9,0 juta km merupakan kawasan pesisir dan lautan. Panjang garis pantai lebih kurang, 81.000 km. Pada garis pantai iniliah terletak wilayah pesisir yang memiliki keanekaragaman bentuk dan ekosistem pantai. ${ }^{2}$

Reklamasi diatur dalam Peraturan Presiden Nomor 122 Tahun 2012 tentang Reklamasi di Wilayah Pesisir dan Pulau-Pulau Kecil (PerpresRDWPDPPK). Perpres tersebut merupakan pelaksanaan ketentuan Pasal 34 ayat 93 Undang-Undang Nomor 1 Tahun 2014 tentang Perubahan atas Undang-Undang Nomor 27 Tahun 2007 tentang Pengelolaan Wilayah Pesisir dan Pulau-Pulau Kecil (UUPWPDPPK). Sebagaimana Perpres di atas, reklamasi adalah kegiatan yang dilakukan oleh orang dalam rangka meningkatkan manfaat sumber daya lahan ditinjau dari sudut lingkungan dan sosial ekonomi dengan cara pengurugan, pengeringan lahan atau drainase. Sedangkan Wisnu Suharto mendefinisikan reklamasi sebagai usaha memanfaatkan lahan yang awalnya tidak berguna menjadi berguna, seperti daerah pantai maupun sungai. ${ }^{3}$

Masyarakat Indonesia sudah banyak yang melakukan reklamasi di daerah pesisir pantai, tidak terkecuali di Desa Taddan Kecamatan Camplong Kabupaten Sampang. Di daerah tersebut di bagian selatan berbatasan dengan laut, sehingga banyak warga yang melakukan reklamasi tanah di pantai. Menurut Musleh selaku Kepala Seksi Hak Tanah dan Pendaftaran Tanah Badan Pertanahan Nasional (BPN) Kabupaten Sampang, alasan seseorang melakukan reklamasi pantai dapat berbeda-beda, mulai dari pembuatan rumah sampai lahan untuk usaha. Akan tetapi, tanah hasil reklamasi tersebut tidak bersertifikat. ${ }^{4}$

l Kertasapoetra, dkk., Hukum Tanah Jaminan UUPA Bagi Keberhasilan Pendayagunaan Tanah, (Jakarta: Bina Aksara, 1984), hlm. 1

2 Rachmad Safa'at dkk, Relasi Negara dan Masyarakat Adat (perebutan kuasa hak atas sumber daya alam), (Malang: Surya Pena Gemilang, 2015), hlm 141

3 Wisnu Suharto, Reklamasi Pantai dalam Perspektif Tata Air,( Semarang:, Unika Soegijapranata, 1996). hlm. 9

4 Wawancara dengan Musleh Kepala Seksi Hak Tanah Dan Pendaftaran Tanah Badan Pertanahan Nasional Kabupaten Sampang Tgl 19 April 2017 
Kabupaten Sampang sendiri mempunyai peraturan yang mengatur tentang tata ruang wilayah yang tertulis dalam Peraturan Daerah Kabupaten Sampang Nomor : 7 Tahun 2012 Tentang Rencana Tata Ruang Wilayah Kabupaten Sampang Tahun 20122032( Selanjutnya disebut Perda RTRWKS). Perda tersebut dibuat untuk mengarahkan pembangunan secara berdaya guna, berhasil guna, serasi, selaras, seimbang dan berkelanjutan dalam rangka meningkatkan kesejahteraan masyarakat dan pertahanan keamanan. Selain itu, juga dalam rangkamewujudkan keterpaduan pembangunan antar sektor daerah, dan masyarakat. Perda RTRWKS merupakan amanat dari Undang-Undang Nomor 26 Tahun 2007 tentang Penataan Ruang (selanjutnya disebut UUPR), Perda RTRWKS menjabarkan tentang perencanaan tata ruang wilayah Kabupaten sesuai paragraf 4 UUPR.

Pasal 35 UUPR menjelaskan tentang pengendalian pemanfaatan ruang yang berbunyi Pengendalian pemanfaatan ruang dilakukan melalui penetapan peraturan zonasi, perizinan, pemberianinsentif dan disinsentif, serta pengenaan sanksi. Ketentuan peraturan zonasi ialah ketentuan yang mengatur tentang persyaratan pemanfaatan ruang dan juga ketentuan pengendaliannya, serta disusun untuk setiap blok/zona peruntukan yang penetapan zonanya dalam rencana rinci tata ruang.

Perda RTRWKS pasal 67 Ayat (1) huruf b menjelaskan tentang peraturan zonasi kawasan perlindungan setempat, yang selanjutnya lebih dijabarkan dalam ayat (3) pasal 67 Perda tersebut. Dalam ayat tersebut dijelasakan bahwa ketentuan umum peraturan zonasi sempadan pantai meliputi perlindungan ekosistem mangrove dari perusakan, gangguan, ancaman, hama, dan penyakit. Selain itu juga disebutkan bahwa tidak diperbolehkan kegiatan budidaya yang dapat mengganggu kelestarian fungsi pantai, merusak kualitas air, kondisi fisik, dan dasar pantai.

Perda RTRWKS pasal 67 Ayat (4) huruf b menjelaskan tentang Ketentuan umum peraturan zonasi kawasan suaka alam, pelestarian alam dan cagar budaya. Dalam ayat tersebut dijelaskan ketentuan umum peraturan zonasi kawasan berhutan bakau yang tidak diperbolehkan pemanfatan ruang yang mengganggu kualitas lingkungan. Penjelasan diatas menjelaskan bahwa Perda RTRWKS mengatur bahwa Pemerintah Kabupaten Sampang berupaya untuk melakukan konservasi terhadap hutan bakau di sepanjang pesisir pantai Kabupaten Sampang. Meskipun konservasi hutan bakau disepanjang pesisir pantai sudah diatur oleh Kabupaten Sampang, akan tetapi masyarakat masih banyak yang melakukan reklamasi tanah di pesisir pantai

Peraturan Pemerintah Republik Indonesia Nomor 16 Tahun 2004 Tentang Penatagunaan Tanah (UUPT) Pasal 12 menjelaskan bahwa Tanah yang berasal dari tanah timbul atau hasil reklamasi di wilayah perairan pantai, pasang surut, rawa, danau, dan bekas sungai dikuasai langsung oleh Negara. Menurut penjelasan pasal 12 UUPT Reklamasi adalah pengurukan wilayah perairan guna memperluas ruang daratan, penggunaan danpemanfaatan tanahnya harus sesuai RTRW. karena pemanfaatan tanah yang tidak sesuai dengan rencana tata ruang wilayah, serta 
memelihara tanah dan mencegah kerusakan tanah tanah. ${ }^{5}$ Oleh sebab itu menurut Bapak Musleh pihak BPN tidak bisa mengeluarkan sertifikat terkait reklamsi tanah pantai tersebut karena berbenturan dengan Perda RTRWKS.

Tujuan pendaftaran tanah menurut Pasal 3 Peraturan Pemerintah Nomor 24 Tahun 1997 Tentang Pendaftaran Tanah (PPPT), yaitu untuk memberikan kepastian hukum dan perlindungan hukum kepada pemegang hak atas suatu bidang tanah selain itu untuk menyediakan informasi kepada pihak-pihak yang berkepentingan. Salah satu syarat pendafataran tanah yaitu pembuktian hak lama seperti yang sudah dijelaskan dalam pasal 24 ayat (1) PPPT. Penguasaan tanah reklamasi yang dilakukan oleh masyarakat Desa Taddan dimulai pada tahun 2008. Sampai saat ini ada sembilan reklamasi yang sudah dilakukan oleh masyarakat. Mereka melakukan reklamasi dengan luas dan alasan yang berbeda. Mereka melakukan reklamasi tersebut secara individu dengan hanya melakukan izin secara lisan kepada kepala desa. Masyarakat desa taddan juga mendirikan bangunan di atas tanah reklamasi tanpa alas hak tersebut. Bangunan yang didirikan oleh masyarakat tersebut tentunya tanpa izin dari pemerintah. Penguasaan tanah reklamasi masyarakat Desa taddan tersebut tanpa alas hak, penguasaan tanpa alas hak yang dilakukan masyarakat tersebut berarti dianggap sebagai penguasaan liar (okupasi).

Rumusan masalah dalam kasus ini adalah, akibat hukum bagi penguasaan tanah reklamasi tanpa alas hak atas tanah. Dan yang kedua, Bagaimana efektivitas penegakan hukum oleh aparat penegak hukum dalam menyelesaikan penguasaan tanah reklamasi tanpa alas hak di Desa Taddan. Sedangkan tujuan penelitian ini yaitu menganalisis akibat hukum dan juga untuk mengetahui serta menganalisis efektivitas penegakan hukum oleh aparat penegak hukum dalam menyelesaikan bagi penguasaan tanah reklamasi tanpa alas hak atas tanah. Teori yang dipakai dalam penelitian ini yaitu teori akibat hokum, teori ha katas tanah, dan teori efektivitas hukum. Penelitian ini menggunakan penelitian hukum empiris. Metode pendekatan yang digunakan yaitu secara yuridis sosiologis. Metode analisis data dilakukan melalui analisis kualitatif.

\section{AKIBAT HUKUM BAGI PENGUASAAN TANAH REKLAMASI TANPA ALAS HAK ATAS TANAH}

Reklamasi tanah di pesisir mempunyai dampak buruk terhadap lingkungan, seperti yang dijelasakan Nurul Hayati Kepala Bidang Perikanan Tangkap Dinas Perikanan Kabupaten Sampang yang menjelasakan bahwa dampak reklamasi yaitu pertama adalah rusaknya mangrove yang berfungi untuk menangkis erosi di pesisir pantai, jika di desa Taddan akan merusak jalan raya yang berbatasan dengan laut. Yang kedua berkurangnya ikan-ikan di pinggir pantai yang mengakibatkan nelayan kesulitan dalam mencari ikan. Menurutnya pihaknya memang tidak menganjurkan untuk diadakannya reklamasi.

Teori akibat hukum menurut Soeroso Akibat yang dimaksud adalah akibat yang diatur oleh hukum, sedangkan tindakan yang dilakukan merupakan tindakan hukum

5 Flora Pricilla Kalal, Implikasi Hukum Kebijakan Reklamasi Pantai dan Laut di Indonesia, (Bandung: Logoz Publishing, 2009) hlm.4 
yaitu tindakan yang sesuai dengan hukum berlaku. ${ }^{6}$ Sedangkan menurut Achmad Ali, akibat hukum adalah suatu akibat yang ditimbulkan oleh hukum, terhadap suatu perbuatan yang dilakukan oleh subjek hukum. Akibat hukum merupakan suatu akibat dari tindakan yang dilakukan, untuk memperoleh suatu akibat yang diharapkan oleh pelaku hukum. ${ }^{7}$ Sedangkan menurut Agus Sudaryanto akibat hukum adalah suatu akibat yang ditimbulkan oleh adanya suatu peristiwa dan atau hubungan hukum ${ }^{8}$ Wujud dari akibat hukum yaitu yang pertama lahirnya, berubahnya atau lenyapnya suatu keadaan hukum. Kedua lahirnya, berubahnya atau lenyapnya suatu hubungan hukum, antara dua atau lebih subyek hukum, di mana hak dan kewajiban pihak yang satu berhadapan dengan hak dan kewajiban pihak yang lain. Dan yang ketiga lahirnya sanksi apabila dilakukan tindakan yang melawan hukum.

Suatu akibat pasti ada penyebabnya, jika melihat dari pengertian menurut Soeroso dan Achmad Ali dapat disimpulkan bahwa akibat yang dilakukan oleh subyek hukum pasti akan menyebabkan tindakan yang diatur dengan hukum yang berlaku. Tindakan hukum dalam kasus di atas adalah, reklamasi tanah di pesisir Desa Taddan yang dilakukan oleh masyarakat tanpa izin dari pihak yang berwenang. Penguasan tanah oleh masyrakat itu sendiri tanpa alas hak atas tanah. Jadi penguasan tanah reklamasi tersebut adalah illegal. Sedangkan subyek hukum dalam hal ini adalah pelaku reklamasi tanpa alas hak atas tanah tersebut.

Teori akibat hukum jika dikaitkan dengan kasus di atas yaitu, Akibat hukum yang dilakukan oleh subyek hukum yang melakukan reklamasi tanah yaitu izin reklamasi harus sesuai dengan prosedur yang sudah tertulis dalam dalam pasal 16 ayat (1) Perpres RDWPDPPK yaitu untuk memperoleh izin lokasi dan izin pelaksanaan reklamasi, Pemerintah, pemerintah daerah dan setiap orang wajib terlebih dahulu mengajukan permohonan kepada Menteri, gubernur, atau bupati/walikota. Akan tetapi subyek hukum dalam kasus reklamasi tersebut tidak melalui prosedur sesuai dengan hukum yang berlaku. Para subyek hukum tersebut melakukan reklamasi hanya dengan izin lisan dari kepala desa Taddan.

Akibat hukum yang pertama yaitu tindakan subyek hukum tersebut berarti tidak sesuai dengan peraturan yang berlaku. Sehingga penguasaan tanah reklamasi di Desa Taddan tersebut tidak memiliki izin sebagaimana yang diatur dalam Perpres RDWPDPPK. Jadi jika subyek hukum tidak mempunyai izin dalam melakukan reklamasi, mereka seharusnya tidak melakukan reklamasi. Reklamasi tanpa alas hak atas tanah selanjutnya mempunyai akibat hukum yaitu, seharusnya subyek hukum tidak boleh menempati tanah reklamasi tersebut. Hal tersebut dijelaskan dalam Peraturan Pemerintah Pengganti Undang Undang No. 51 Tahun 1960 Tentang : Larangan Pemakaian Tanah Tanpa Ijin Yang Berhak Atau Kuasanya Selanjutnya disebut Perppu 51/1960. Perppu tersebut dikeluarkan untuk perlindungan tanah tanah terhadap pemakaian tanpa ijin yang berhak atau kuasanya yang sah. Dalam pasal

\footnotetext{
Soeroso, Pengantar Ilmu Hukum, (Jakarta: Sinar Grafika, 2006), hlm. 295

Achmad Ali, Menguak Tabir Hukum, (Jakarta: Kencana, 2008), hlm. 192

Agus Sudaryanto, Pengantar Ilmu Hukum(Malang:Setara Press, 2015), hlm. 65
} 
2 Perppu 5l/1960 dijelaskan Dilarang memakai tanah tanpa ijin yang berhak atau kuasanya yang sah.

Teori Hak atas tanah menjelaskan bahwa sumber hak atas tanah berasal dari hak menguasai negara atas tanah yang dapat diberikan kepada perorangan, baik warga negara Indonesia maupun warga negara asing, sekelompok orang secara bersama-sama, dan badan hukum, baik badan hukum privat maupun badan hukum publik. Menurut Soedikno Mertokusumo, wewenang yang dipunyai oleh pemegang hak atas tanah terhadap tanahnya dibagi menjadi dua, yaitu wewenang umum dan khusus ${ }^{9}$

Wewenang umum dan wewenang khusus yang dijelaskan oleh Soedikno Mertokusumo bertentangan dengan keadaan yang terjadi di Desa Taddan. Dalam teori tersebut dijelaskan bahwa pemegang hak atas tanah mempunyai wewenang baik wewenang umum maupun wewenang khusus mempunyai wewenang untuk menggunakan tanahnya. Akan tetapi masyarakat yang melakukan reklamasi di desa Taddan tersebut tidak mempunya alas hak atas tanah, dengan begitu mereka tidak mempunyai wewenang untuk menggunakan tanahnya.

Akibat hukum yang kedua yaitu, subyek hukum tidak bisa mendirikan bangunan di atas tanah reklamasi. hal itu dikarenakan subyek hukum tidak mempunyai hak atas tanah di atas reklamasi tanah tersebut. Moh. Jalil Kepala Seksi Penyidikan dan Penindakan Satpol PP Kabupaten Sampang menjelaskan bahwa bangunan-bangunan yang berdiri di atas tanah reklamasi tersebut tidak berizin. Soalnya, untuk mendirikan bangunan tersebut juga harus ada sertifikat hak atas tanahnya. Sedangkan mereka hak atas tanahnya tidak ada, karena BPN katanya tidak mengeluarkan sertifikat dikarenakan reklamasi tersebut bertentangna dengan perda dan juga reklamasinya tanpa izin sesuai prosedur ${ }^{10}$

Undang-Undang Republik Indonesia Nomor 28 Tahun 2002 Tentang Bangunan Gedung (UUBG) Pasal 7 menjelaskan tentang syarat didirikannya bangunan gedung harus mempunyai Persyaratan administratif bangunan gedung sebagaimana dimaksud dalam ayat (1) meliputi persyaratan status hak atas tanah, status kepemilikan bangunan gedung, dan izin mendirikan bangunan. Dalam Pasal 7 ayat (2) dijelaskan bahwa salah satunya adalah status hak atas tanah. Akan tetapi dalam kenyataannya di Desa Taddan ada sembilan reklamasi tanah di mana tujuh diantaranya dibangun bangunan di atas tanah tersebut tanpa hak atas tanah.

Akibat hukum ketiga adalah tanah reklamasi tanpa alas hak atas tanah bisa digusur oleh pihak berwenang. Akan tetapi sampai saat ini belum ada tindakan dari pihak berwenang terhadap reklamasi tanah di Desa Taddan tersebut. Karena tidak ada tindakan dari pihak berwenang, maka kasus penguasaan tanah reklamasi tanpa alas haka atas tanah di Desa Taddan maupun di desa-desa lain semakin banyak dan tak terkendali. Sejak berlakunya UUPA ada tiga macam jenis tanah di Indonesia, yaitu: ${ }^{11}$ Yang pertama adalah Tanah Negara yaitu, tanah yang diatasnya belum terdapat atau

\footnotetext{
${ }^{9}$ Urip Santoso, Loc. cit

${ }^{10}$ Wawancara dengan Moh. Jalil Kepala Seksi Penyidikan dan Penindakan Satpol PP Kabupaten Sampang 21 Agustus 2017 jam 13. 15

${ }^{11}$ Urip Santoso, Pendaftaran dan Peralihan Hak Atas Tanah (Jakarta: Kencana, 2013) hlm. 209
} 
belum dibebani dengan hak atas tanah tertentu. Yang kedua Tanah hak, yitu tanah yang di atasnya sudah terdapat atau sudah dibebani dengan hak atas tanah tertentu. Dan yang ketiga Tanah ulayat yaitu, tanah yang dikuasai secara bersama-sama oleh masyarakat hukum adat Pasal 12 UUPT menjelaskan bahwa Tanah yang berasal dari tanah timbul atau hasil reklamasi di wilayah perairan pantai, pasang surut, rawa, danau, dan bekas sungai dikuasai langsung oleh Negara. Tanah hasil reklamasi di Desa Taddan tersebut merupakan tanah yang tidak bisa dilekati alas hak atas tanah karena berbenturan dengan peraturan yang berlaku. Jadi tanah reklamasi di Desa Taddan merupakan tanah yang diatasnya belum terdapat atau belum dibebani dengan hak atas tanah tertentu, dengan kata lain tanah tersebut merupakan tanah Negara.

Akibat hukum selanjutnya yaitu tanah hasil reklamasi tersebut tidak bisa didaftarkan hak atas tanahnya oleh seorang yang melakukan reklamasi dikarenakan bertentangan dengan peraturan yang berlaku. Dikarenakan tidak terdaftar, sehingga tanah tersebut menjadi Tanah Negara. Tanah Negara menurut pasal 1 angka 4 UUPA adalah Tanah Negara atau tanah yang dikuasai langsung oleh Negara adalah tanah yang tidak dipunyai dengan sesuatu hak atas tanah.

Maria S.W Sumardjono dalam Julius Sembiring menjelaskan bahwa ruang lingkup tanah negara salah satunya adalah Tanah timbul dan tanah reklamasi. ${ }^{12}$ Maria S.W Sumardjono menyebutkan tujuh ruang lingkup tanah Negara, dimana salah satunya adalah tanah reklamasi. Tanah Negara yang berasal dari reklamasi tersebut menurut pasal 9 PPPT menjadi salah satu obyek pendaftaran tanah. Dalam hal tanah Negara sebagai obyek pendaftaran tanah sebagaimana dimaksud pada ayat (l) huruf f, pendaftarannya dilakukan dengan cara membukukan bidang tanah yang merupakan tanah Negara dalam daftar tanah

Pasal 9 PPPT menjelaskan bahwa tanah Negara seharusnya didaftarkan. Menurut penjelasan pasal 21 ayat (l) PPPT, daftar tanah dimaksudkan sebagai sumber informasi yang lengkap mengenai nomor bidang lokasi dan penunjukan ke nomor surat ukur bidang-bidang tanah yang ada di wilayah pendaftaran, baik sebagai hasil pendaftaran untuk pertama kali maupun pemeliharaannya kemudian.

Kepala Subseksi Pemeliharaan Data Hak Atas Tanah dan Pembinaan Pejabat Pembuat Akta Tanah Badan Pertanahan Nasional Kabupaten Sampang, Bapak Riadi Santoso menjelaskan BPN Sampang hanya mengurus permohonan hak saja. Seharusnya Pemkab yang menertibkan itu. ${ }^{13}$ Jadi, BPN Kabupaten Sampang sampai saat ini belum mendata dan mendaftarkan tanah-tanah negara yang berasal dari reklamasi di pesisir Desa Taddan maupun desa-desa yang lainya.

12 Julius Sembiring, Tanah Negara, (Jakarta: Prenada media, 2016) hlm 14

13 Wawancara dengan Riadi Santoso Kepala Subseksi Pemeliharaan Data Hak Tanah dan Pembinaan Pejabat Pembuat Akta Tanah Badan Pertanahan Nasional Kabupaten Sampang, tgl 1 Agustus 2017 jam 8.30 


\section{EFEKTIVITAS PENEGAKAN HUKUM OLEH APARAT PENEGAK HUKUM}

Penegakan hukum adalah suatu proses untuk mewujudkan keinginana-keinginana hukum menjadi kenyataan. Penegakan hukum itu sendiri adalah suatu proses untuk mewujudkan keinginan-keinginan hukum menjadi kenyataan, yang disebut sebagai keinginan-keinginan hukum disini adalah pikiran-pikiran badan pembuat undangundang yang dirumuskan dalam peraturan hukum itu ${ }^{14}$ Secara konsepsional, inti dan arti penegakan hukum terletak pada kegiatan menyerasikan hubungan nilai-nilai yang terjabarkan di dalam kaidah-kaidah yang mantap dan mengejawantah dan sikap tindak sebagai rangkaian penjabaran nilaitahap akhir, untuk menciptakan, memelihara dan mempertahankan kedamaian pergaulan hidup. ${ }^{15}$

Lawrence M. Friedman menyatakan bahwa efektif atau tidaknya suatu perundang-undangan sangat dipengaruhi oleh tiga faktor yaitu substansi hukum, struktur hukum, dan budaya hukum. Penulis akan menggunakan teori efektivitas hukum dari Soerjono Soekanto, dikarenakan ketiga faktor yang dijelaskan Friedman berada dalam lima faktor-faktor efektivitas penegakan hukum yang diuraikan Soerjono Soekanto. Selanjutnya di bawah ini akan dijelaskan faktor efektivitas penegakan hukum terhadap reklamasi tanpa alas haka atas tanah yang terjadi di Desa Taddan

Faktor pertama adalah faktor Undang-undang. Undang-undang yang dimaksud adalah peraturan terkait dalam kasus reklamasi tanah tanpa alas hak. Gangguan terhadap penegakan hukum yang berasal dari undang-undang mungkin disebabkan oleh, yang pertama tidak diikutinya asas-asas undang-undang. Yang kedua belum adanya peraturan pelaksana yang sangat dibutuhkan. Dan yang ketiga ketidakjelasan arti kata-kata di dalam undang-undang yang mengakibatkan kesimpangsiuran di dalam penafsiran serta penerapannya. ${ }^{16}$ Reklamsai yang dilakukan oleh masyarakat desa Taddan melanggar konservasi mangrove yang dilakukan oleh Kabupaten Sampang yang tertulis dalam pasal 67 RTRWKS. Akan tetapi Pemerintah Kabupaten Sampang menyatakan bahwa sejak dikeluarkannya Undang-undang No. 23 Tahun 2014 tentang Peraturan Daerah (UUPD), yang mengelola daerah pesisir bukan dari Kabupaten, akan tetapi dari Provinsi Jawa Timur sesuai dengan Ayat (3) pasal 27 UUPD yang yang menjelasakan bahwa Provinsi mempunyai kewenangan untuk mengelola sumber daya alam di laut paling jauh 12 mil diukur dari garis pantai kea rah laut lepas.

Dinas Kelautan dan Perikanan Provinsi Jawa Timur sendiri yang diwakili oleh Wahyu selaku Kepala Seksi Pengelolaan Ruang Laut menyatakan bahwa Dinas tersebut saat ini sedang membuat Rancangan Peraturan Daerah tentang daerah pesisir dan zonasi tersebut yang sampai saat ini belum selesai dan belum disahkan. hal itulah

\footnotetext{
14 Satjipto Raharjo Masalah Penegakan Hukum Suatu Tinjauan Sosiologis, (Bandung: Sinar Baru. Bandung 1983). hlm. 24

15 Soerjono Soekanto, Faktor-faktor Yang Mempengaruhi Penegakan Hukum, (Jakarta:Rajawali Pers, 2014) hlm 5

$16 \quad$ Ibid hlm .17
} 
yang membuat pihak pemertintah Provinsi Jawa Timur belum bisa melakukan penertiban terhadap reklamasi di jawa timur. ${ }^{17}$

Perppu 51/1960 mengatur tentang larangan pemakaian tanah tanpa ijin yang berhak atau kuasanya dalam pasal 2 Perppu 51/1960 dijelaskan Dilarang memakai tanah tanpa ijin yang berhak atau kuasanya yang sah. Akan tetapi yang menjadi permasalahan dalam Perppu 5l/1960 seharusnya diperbaharui lagi, semakin bergulirnya waktu, maka perlu beberapa pembaharuan untuk mengimbangi perkembangan zaman. Dalam perppu tesebut dikhususkan untuk daerah-daerah yang berada dalam keadaan bahaya dengan tingkatan keadaan darurat sipil, darurat militer atau keadaan perang, masingmasing penguasa daruruat sipil daerah, penguasa darurat militer daerah atau penguasa perang.

Peraturan tersebut digunakan untuk masa-masa darurat dan pemberontakan sesaat setelah Indonesia merdeka. Seharusnya undang-undang yang berbasis pada keadaan bahaya tidak berlaku lagi. Seperti yang diungkapkan Kepala Subseksi Pemeliharaan Data Hak Tanah dan Pembinaan Pejabat Pembuat Akta Tanah Badan Pertanahan Nasional Kabupaten Sampang, Bapak Riadi menjelaskan bahwa perppu tersebut sudah tidak cocok dengan keadaan Indonesia saat ini. Maka Perppu 51/1960 bisa disimpulkan bahwa adanya ketidakjelasan arti kata-kata "keadaan bahaya" di dalam peraturan tersebut yang mengakibatkan kesimpangsiuran di dalam penafsiran serta penerapannya. Apakah kata "keadaan bahaya" masih bisa diterapkan dalam keadaan Indonesia saat ini atau tidak.

Faktor hukum kedua yaitu faktor penegak hukum. Dalam kasus reklamasi tanpa alas hak atas tanah di Desa Taddan banyak pihak yang terlibat dalam kasus ini. Dimulai dari Pemerintah Desa Taddan sendiri. Hasil wawancara penulis dengan perangkat Desa taddan yaitu Bapak Anang Zaini beliau sebagai perwakilan dari Kepala Desa Taddan dalam wancara penelitian ini. Beliau menjelaskan bahwa pemerintah desa Taddan memang tidak menganjurkan melakukan reklamasi tanah di sepanjang pesisir Desa Taddan, akan tetapi pemerintah Desa Taddan juga tidak bisa melarang reklamasi tanah di Desa Taddan. ${ }^{18}$

Penjelasan dari Anang Zaini tersebut menunjukkan bahwa pemerintah Desa Taddan tidak tegas dalam menindak pelaku reklamasi tanpa alas hak atas tanah tersebut. Meskipun mereka mengatakan bahwa tidak menganjurkan reklamasi ilegal, akan tetapi izin reklamasi tersebut berdasarkan persetujuan dari Kepala Desa Taddan. Hal itu tidak sesuai dengan bumyi Pasal 16 ayat (1) Perpres RDWPDPPK yang menjelasakan tentang izin memperoleh lokasi, setiap orang wajib terlebih dahulu mengajukan permohonan kepada Menteri, Gubernur, atau Bupati/Walikota.

Bapelitbangda Kabupaten Sampang sendiri juga mengatakan bahwa pihaknya tidak mempunyai wewenang terhadap penertiban reklamasi tanah tersebut. Kepala Sub Bidang Penataan Ruang dan Permukiman Bapelitbangda Kabupaten Sampang, Bapak Achmad Chozin menjelaskan bahwa reklamasi sebenarnya tidak diperbolehkan, karena berbenturan dengan

\footnotetext{
17 Wawancara dengan Wahyu Kepala Seksi Pengelolaan Ruang Laut Dinas Kelautan dan Perikanan Provinsi Jawa Timur tgl 10 Oktober 2017 jam 08.15

18 Wawancara dengan Anang Zaini perangkat Desa Taddan tgl 21 Agustus 2017 jam 12. 30
} 
Perda RTRWKS. Akan tetapi, sejak sejak dikeluarkannya UU Nomor 23 Tahun 2014 tentang Pemerintah Daerah, wilayah 0 sampai 12 mil ke arah laut merupakan wewenang Provinsi yaitu Dinas Kelautan dan Perikanan Provinsi Jawa timur. ${ }^{19}$

Dinas Kelautan dan Perikanan Provinsi Jawa Timur sendiri seperti yang sudah dijelaskan di atas menyatakan bahwa pihaknya saat ini sedang membuat Rancangan Peraturan Daerah tentang daerah pesisir dan zonasi tersebut. Reklamasi tanpa alas hak atas tanah erat kaitannya dengan BPN yang mengurus tentang pertanahan. BPN Kabupaten sampang seakan tidak peduli terhadap reklamasi tersebut dan mengatakan bahwa reklamasi reklamasi tersebut adalah wewenang pemkab. Kepala Subseksi Pemeliharaan Data Hak Tanah dan Pembinaan Pejabat Pembuat Akta Tanah Badan Pertanahan Nasional Kabupaten Sampang, Bapak Riadi Santoso menjelaskan BPN Sampang hanya mengurus permohonan hak saja. ${ }^{20}$

Tanah Negara yang berasal dari reklamasi tersebut menurut pasal 9 PPPT menjadi salah satu obyek pendaftaran tanah. Pasal 9 ayat (1) PPPT menjelaskan bahwa tanah Negara seharusnya didaftarkan. Tanah Negara seharusnya didaftarkan dalam daftar tanah. Menurut penjelasan pasal 21 ayat (1) PPPT, daftar tanah dimaksudkan sebagai sumber informasi yang lengkap mengenai nomor bidang lokasi dan penunjukan ke nomor surat ukur bidang-bidang tanah yang ada di wilayah pendaftaran, baik sebagai hasil pendaftaran untuk pertama kali maupun pemeliharaannya kemudian.

Soerjono Soekanto menjelasakan dalam beberapa halangan yang mungkin dijumpai pada penerapan peranan yang seharusnya dari golongan sasaran atau penegak hukum, halangan-halangan tersebut salah satunya keterbatasan kemampuan untuk menempatkan diri dalm peranan pihak lain dengan siapa dia berinteraksi. BPN Kabupaten Sampang seharusnya bisa bekerjasama dengan dinas-dinas lain yang terkait untuk menyelesaikan permasalahan reklamasi tanpa alas hak atas tanah tersebut.

Faktor efektivitas ketiga adalah sarana dan fasilitas. Tanpa adanya sarana atau fasilitas tertentu maka tidak mungkin penegakan hukum akan berlangsung dengan lancar. Sebelum dikeluarkannya UUPD tahun 2014 yang salah satunya mengatur tentang pesisir yang menjadi wewenang Provinsi Jawa Timur, Satuan Polisi Pamong Praja Kabupaten Sampang pernah melakukan pendataan dan sosialisasi terkait reklamasi tanpa alas hak atas tanah tersebut. Seperti yang dijelaskan Moh. Jalil selaku Kepala Seksi Penyidikan dan Penindakan Satpol PP Kabupaten Sampang menjelaskan bahwa pihaknya sekarang tidak mempunyai wewenang terhadap reklamasi tersebut sejak dikeluarkan UUPD. ${ }^{21}$

BPN Kabupaten Sampang seperti yang sudah dijelaskan di atas tidak mencatatkan reklamasi tanpa alas hak atas tanah tersebut dalam daftar tanah sesuai dengan pasal 9 PPPT yang menjelaskan bahwa tanah Negara seharusnya didaftarkan.

19 Wawancara dengan Kepala Sub Bidang Penataan Ruang dan Permukiman Bappeda Kabupaten Sampang, Bapak Achmad Chozin tanggal 25 Juli 2017

20 Wawancara dengan Riadi Santoso Kepala Subseksi Pemeliharaan Data Hak Tanah dan Pembinaan Pejabat Pembuat Akta Tanah Badan Pertanahan Nasional Kabupaten Sampang, tgl 1 Agustus 2017 8.30

21 Wawancara dengan Moh. Jalil Kepala Seksi Penyidikan dan Penindakan Satpol PP Kabupaten Sampang 21 Agustus 2017 jam 13. 15 
Penjelasan di atas bisa diketahui bahwa tidak ada sarana yang dari BPN Kabupaten Sampang untuk memfasilitasi data reklamasi untuk didaftarkana dalam daftar tanah. Sehingga tidak ada data terkini terhadap masyarakat desa Taddan yang melakukan reklamasi tanpa alas hak atas tanah tersebut.

Faktor yang keempat yang menentukan efektivitas penegakan hukum adalah faktor masyarakat, dalam teori tersebut juga tidak sejalan dengan peraturan yang berlaku. Hal tersebut bisa dilihat dari paparan diatas yaitu, masyarakat desa Taddan tidak sepenuhnya mematuhi dan memahami peraturan yang sudah berlaku. Masyarakat desa Taddan melanggar PerpresRDWPDPPK, Perda RTRWKS dan Perppu 51/1960 untuk melakukan reklamasi tanpa alas hak atas tanah dengan berbagai macam alasan.

Khairul Anwar, Mansur, Rusdi dan Saniwan mengatakan bahwa pesisir yang ada di seberang jalan rumahnya adalah miliknya. Tentunya pemahaman tersebut tidaklah benar, tidak ada satupun peraturan yang mengatur seperti yang diucapkannya. Dari pernyataan tersebut dapat dilihat bahwa kurangnya pemahaman masyarakat terhadap peraturan pertanahan. Masih menurut mereka, BPN kabupaten Sampang tidak pernah melakukan sosialisasi dalam pemahaman hak atas tanah. Bapak Anang Zaini selaku perwakilan dari pemerintah Desa Taddan juga menjelasakan bahwa masyarakat desa Taddan menganggap tanah pesisir seberang rumahnya adalah tanahnya sendiri. Penjelasan dari Anang Zaini tersebut bisa disimpulkan bahwa masyarakat desa Taddan masih kurang memahami penjelasan tentang hak atas tanah. Sehingga mereka dengan ketidaktahuannya tersebut dijadikan alasan untuk melakukan reklamasi tanah tanpa alas haka atas tanah.

Faktor efektivitas penegakan hukum yang selanjutnya adalah faktor kebudayaan. Menurut Soerjono Soekanto, pasangan nilai yang berperan dalam hukum salah satunya adalah nilai ketertiban dan nilai ketentraman. Masyarakat Madura dikenal mempunyai watak yang keras, tidak jarang karena masalah kecil terjadi carok. Carok menurut pengertian Kamus Besar Bahasa Indonesia adalah berkelahi dengan menggunakan senjata tajam (clurit). Memang tidak semuanya orang Madura mempunyai watak yang yang keras dan mudah tersinggung lalu melakukan carok. Seperti yang diungkapkan Anang Zaini perangkat desa Taddan menjelaskan pihak Desa memang tidak menganjurkan reklamasi, tapi pihaknya juga tidak berani melarang, karena watak orang Madura yang dikenal keras. ${ }^{22}$ Uraian di atas dapat disimpulkan bahwa dari Efektivitas penegakan hukum yang terdiri dari faktor Undang-undang, penegak hukum, sarana dan fasilitas, Masyarakat, dan budaya hukum bisa dikatan bahwa kelima faktor tersebut belum berjalan dengan baik. Sehingga penguasaan reklamasi tanpa alas hak atas tanah masih belum bisa teratasi.

\section{KESIMPULAN}

Akibat-akibat hukum yang terjadi terhadap reklamasi tanpa alas hak atas tanah adalah, pertama subyek hukum tidak bisa menguasai tanah reklamasi. Kedua subyek hukum

22 Anang Zaini, supra note 18. 
tidak boleh mendirikan bangunan di atas tanah reklamasi tanpa alas hak atas tanah, Ketiga bangunan yang didirikan diatas tannah reklamasi tanpa alas hak bisa digusur tanpa ganti rugi. Keempat tanah reklamasi harus didaftarkan dalam daftar tanah di BPN sebagai tanah Negara. Sedangkan Faktor-faktor efektivitas penegakan hukum yang yang terdiri dari faktor Undang-undang, penegak hukum, faktor sarana atau fasilitas, faktor masyarakat, faktor kebudayaan dalam kasus reklamasi tanah tanpa alas hak atas tanah masih belum bisa ditegakkan

\section{DAFTAR PUSTAKA}

Anang Zaini perangkat Desa Taddan tgl 21 Agustus (2017).

Flora Pricilla Kalal, Implikasi Hukum Kebijakan Reklamasi Pantai dan Laut di Indonesia, Bandung: Logoz Publishing, 2009.

Julius Sembiring, Tanah Negara, Jakarta: Prenada media, 2016.

Kepala Sub Bidang Penataan Ruang dan Permukiman Bappeda Kabupaten Sampang, Bapak Achmad Chozin 2017.

Kertasapoetra, dkk., Hukum Tanah Jaminan UUPA Bagi Keberhasilan Pendayagunaan Tanah, Jakarta: Bina Aksara, 1984.

Moh. Jalil Kepala Seksi Penyidikan dan Penindakan Satpol PP Kabupaten Sampang (2017).

Musleh Kepala Seksi Hak Tanah Dan Pendaftaran Tanah Badan Pertanahan Nasional Kabupaten Sampang (2017).

Nurul Hayati Kepala Bidang Perikanan Tangkap Dinas Perikanan Kabupaten Sampang $\operatorname{tgl}(2017)$.

Riadi Santoso Kepala Subseksi Pemeliharaan Data Hak Tanah dan Pembinaan Pejabat Pembuat Akta Tanah Badan Pertanahan Nasional Kabupaten Sampang (2017).

Rachmad Safa'at dkk, Relasi Negara dan Masyarakat Adat (perebutan kuasa hak atas sumber daya alam), Malang: Surya Pena Gemilang, 2015.

Urip Santoso, Pendaftaran dan Peralihan Hak Atas Tanah Jakarta: Kencana, 2013.

Wisnu Suharto, Reklamasi Pantai dalam Perspektif Tata Air, Semarang: Unika Soegijapranata, 1996.

Winarno Surachmad, Dasar dan Tehnik Research: Pengertian Metodologi Ilmiah, Bandung: CV. Tarsito 1973.

Soerjono Soekanto, Faktor-faktor Yang Mempengaruhi Penegakan Hukum, Jakarta: Rajawali Pers, 2014.

Wahyu, Kepala Seksi Pengelolaan Ruang Laut Dinas Kelautan dan Perikanan Provinsi Jawa Timur (2017). 